\title{
Impact of Classroom Physical Environment in Reading among Early Graders in Nepalese School
}

\author{
Bhagwan Aryal
}

\begin{abstract}
This article presents the findings of a research aiming to assess classroom physical environment and its link with students' learning achievements in reading Nepali and Mathematic subjects. Physical facilities such as adequacy of space, seating arrangement, comfort inside classroom, placement of chalk/white boards and their sizes, and light and ventilation, display of materials, etc. have an impact on reading among early graders in Nepalese schools. The comparative study assessed the reading comprehension and fluency of Nepali subject together with basic skills of Mathematics of early graders in grades Two and Three.
\end{abstract}

Index Terms - Classroom physical environment, reading, early grade, Nepal, fluency, comprehension.

\section{INTRODUCTION}

Basic literacy is foundation of all kinds of learning. Moreover, ability to read and extract meaning from text is considered to be a fundamental goal of literacy. Reading in fact is a complex cognitive act. According to national Research council book written by Snow, Burns and Griffin reading involves multiple cognitive, emotional, and social abilities[1], each of which impacts the beginning reader's success.

Early grade reading habit of children lays the foundation of their later development. To highlight this, Gove and Cvelich state that children who fail to learn to read in the first few grades of school are handicapped in later grades as they must absorb increasing amounts of instructional content in print form[2].

Ministry of Education (MoE) has prepared National Early Grade Reading Strategy 2015 to 2020 and has invited all International/Non-government organizations (I/NGOs) and development partners to support in the implementation of the strategy[3]. Plan International Nepal is also one of the developmental partners in supporting early grade reading programs in Nepal.

RTI International (2009) indicates that learning to read both early and at a sufficient rate is essential for learning to read well which becomes more difficult for the students when they grow older. Children who do not learn to read in the first few grades are more likely to repeat grades and eventually drop out. And the gap between early readers and non-readers increases over time.

Nepal School Sector Reform Plan (SSRP, 2009-2015) has set the purpose of providing basic education to ensure children's entry into school at the age of six with basic reading skills in

Bhagwan Aryal, PhD, assistant Professor in Central Department of Education, Tribhuvan University, Nepal. order to continue their stay in schools by valuing their personal worth and meaningful participation. SSRP further intends to improve the quality of learning with the support of physical and instructional facilities, competent and qualified teachers, relevant curricula, textbooks and assessment system and result based management system[4]. Akhihiero also concludes that school children who are made to learn under poor provisions of infrastructural facilities become half-baked, and therefore, cannot be useful to themselves and the nation[5]. Education does not exist in a vacuum but in an environment structured of physical facilities and material resources that are used in teaching and learning [6]. "If physical facilities are available and judiciously utilized to meet the needs of the students, this could invariably facilitate students' interest in learning and lead to high performance"'[7].

The purpose of reading is comprehension. Understanding the concepts read or heard is comprehension [2]. Reading comprehension is a constructive process and that meaning is as dependent on the reader as it is on the text. Comprehension should be developed from the very start among learners.

Discussion around early grade reading in Nepal has raised issue of language of instruction among others, as in many countries, laying more emphasis on language teaching rather than building reading competency as specific skill area. However, it is observed that the physical facilities inside classrooms also influence abundantly in this matter. There is a gap in reading ability between the students of public and institutional schools in Nepal which is also accounted due to the lack of adequate physical facilities in public schools.

\section{Objectives}

The objective of thisstudy was to assess the classroom physical environment and its link with early grade students' learning achievements in Nepali and Mathematic subjects. It was focused on finding to what extent Nepali and Mathematics reading comprehension and fluency are affected by the physical facilities such as adequacy of space, seating arrangement, comfort inside classroom, placement of chalk/white boards and their sizes, light, ventilation, and display of materials.

\section{Methodology}

Quantitative research design was used to assess the impact of physical facilities on children's Nepali reading and comprehension and Mathematics skills. Analysis of the findings followed a comparative design, i.e. comparison of achievement and other outcome variables of students between the supported schools (supported to improve physical facilities by Plan International Nepal) and non-supported schools (normal public schools without external support). 
An integrated test was developed in Nepali and Mathematics subjects for Grade 2 and Grade 3 students to assess their Nepali reading ability and basic Mathematics skills. The test had two parts - Part I Nepali and Part II Mathematics, each with five test items and five full marks, thus the score ranged from 0 to 5. The Nepali test in both grades contained a short reading paragraph and five comprehension questions following it. The questions were to answer in a single word or select the correct one from the given options. Similarly, the Mathematics test included five similar questions from the Grade Two and Three Mathematics curricula. Students were asked to answer the question in one word or select the correct one from the given distractors (alternatives or multiple-choice items). One hour was provided to complete both the reading and Mathematics tests.

In order to assess reading fluency, a separate passage was developed for Grade Two and Grade Three students. Individual students were asked to read aloud the paragraph within one minute and teachers/researchers counted the words pronounced correctly within the given time. The tests were conducted among 427 students of grades Two and Three of the 17 public schools, of which Eight schools were Plan supported and Nine schools were without plan's support in EGR. Two schools each from both categories in each district were selected, however in case of Morang district, one additional school was taken to fulfill the sample size. More than fifty percent of the participants of the tests were girl students $(54.56 \%)$.

An observation checklist was used to collect information about the physical aspects of the classroom and availability of reading materials. The classroom space, seating arrangements, displays of reading and other learning materials, use of board, etc. were observed in grades Two and Three of the selected schools.

The tools were pretested and revised prior to the fieldwork. The research tools were trialed in Sindhuli district for their difficulty level, required time and objectivity. A workshop was organized before piloting the tools in order to orient the enumerators. All the tools were revised on the basis of pilot and experience of the enumerators and researchers.

The quantitative data obtained from test and checklist were analyzed using statistical software - Statistical Package for Social Sciences (SPSS) 16 Version. The basic statistical operation such as frequency, percentage, mean and correlation were used to draw meaning from the quantitative data and the results were presented in meaningful tables. The data were transcribed, coded, compared and grouped. This process provided certain themes which were used to explain and triangulate the quantitative results.

This study considered measures to maintain the integrity and ethics of the research endeavors. On every aspect, the respect was paid to the children (to their parents and teachers if necessary) of their rights to participate or not participate in the research process. Boys' and girls' participants were paid equal respect. Verbal consent was taken before administration of the tools. In the tests, privacy of the respondents was maintained and they were assured of the confidentiality of the data and anonymity of the persons involved. Being a social research dealing with children, appropriate measures were used to inform the children and their parents, teachers, and other stakeholders about the aims of the research, the advantages expected from it, and any possible hazards or inconveniences. In addition, the tools were made child friendly, inclusive and appropriate in terms of language, precision and dealing.

\section{Classroom Physical Environment and Students' Learning Achievement}

Positive learning environment provides the space for children to participate in learning activities. As a result of this, children obviously have opportunities to learn. Hannah suggested having positive learning environment in the classroom for students' learning achievement and the development of teachers' positive attitude as well. Facility evaluation by school administration would warrant equitable scrutiny and effort to that of ventures into pedagogy and curriculum[8]. School facility design impacts student achievement, behavior, attendance and teacher retention [8].

Akomolafe and Adesua also highlight that availability and effective utilization of school physical facilities play a significant role in enhancing students' academic performance, while inadequacy of such physical facilities could contribute to poor academic performance[9]. Similarly, Schneider states "School facilities affect learning andspatial configurations, noise, heat, cold, light, and air quality obviously bear on students' and teachers' ability to perform" [10].

Keeping this in mind the study explored the situation of classroom physical environment including adequacy of space, seating arrangement, placement of chalk/white boards and their sizes, and light and ventilation, etc. and its impact on reading in Nepalese schools.

\section{Availability of adequate space in classroom}

Adequate space in classroom plays a vital role in students learning. Spaces for desk bench only may not be sufficient for learning activities. For example, if a teacher is willing to have a small group discussion of small project works in group, normal classroom will not fulfill the needs of such activities. Therefore, adequate space in classroom is a must. In the present study, attempt was made to observe whether or not the schools have adequate space in classroom and their effects on the learning achievement.

Table 1: Adequacy of space in classroom

\begin{tabular}{|l|c|c|}
\hline \multirow{2}{*}{} & \multicolumn{2}{|c|}{$\begin{array}{c}\text { Adequate space in } \\
\text { classroom }\end{array}$} \\
\cline { 2 - 3 } & Yes & No \\
\cline { 2 - 3 } & $\mathrm{N}$ & $\mathrm{N}$ \\
\hline Supported school & 6 & 2 \\
\hline Non-supported school & 4 & 5 \\
\hline Total & 10 & 7 \\
\hline $\begin{array}{l}\text { Average of Nepali and } \\
\begin{array}{l}\text { Mathematics reading (Score } \\
\text { range: } 0 \text { to 5) }\end{array}\end{array}$ & 2.31 & 1.42 \\
\hline Average in fluency & 14.10 & 7.44 \\
\hline
\end{tabular}

Table 1 indicates that out of 17 schools, 10 schools had adequate space in classroom. Out of 10, six schools were supported.TheTable also shows that children's achievements in Nepali and Mathematics were slightly better in those schools with adequate space in classroom as compared to schools having less space. As far as reading fluency of students was concerned, students having adequate space in classroom had better results. It means that adequate space in 
classroom positively influenced the students' reading comprehension and fluency.

\section{Seating arrangement in classroom}

It is assumed that seating arrangement in the classroom can impact the learning achievement of the students. It is a general tendency that the talented students always sit in front rows whereas the weak students sit at the back. It is also true that most of the students occupy the same seats almost every day. Students sitting in the front rows are attentive as compared to the back benchers. They are frequently interacting in the classrooms. Therefore, an attempt was made to observe the provision of seating arrangement of supported and non-supported schools in the study area.

Table 2: Seating arrangement in classroom

\begin{tabular}{|l|c|c|}
\hline \multirow{2}{*}{} & \multicolumn{2}{|c|}{$\begin{array}{c}\text { Proper seating } \\
\text { arrangement in } \\
\text { classroom }\end{array}$} \\
\cline { 2 - 3 } & Yes & No \\
\cline { 2 - 3 } & $\mathrm{N}$ & $\mathrm{N}$ \\
\hline Supported school & 8 & 0 \\
\hline Non-supported school & 6 & 3 \\
\hline Total & 14 & 3 \\
\hline $\begin{array}{l}\text { Average of Nepali and } \\
\text { Mathematics reading (Score } \\
\text { range: O to 5) }\end{array}$ & 2.24 & 0.57 \\
\hline Average in fluency & & \\
\hline
\end{tabular}

It is evident from table 2 that all supported schools 8 had good seating arrangement whereas only six out of nine schools of non-supported schools had those arrangements. While compared to the learning achievement of the students with the provision of seating arrangement, it was found that the mean score of both the comprehension ability and fluency were found to be high. Therefore, it can be concluded that seating arrangement could impact the reading comprehension and reading fluency of the students.

\section{Comfort inside classroom}

As we know that students who are not feeling comfortable while sitting, they are distracted. They cannot be attentive. Therefore, the sitting positions of the students to determine whether or not they were comfortable were observed.

Table 3: Comfort inside classroom

\begin{tabular}{|l|c|c|}
\hline \multirow{2}{*}{} & \multicolumn{2}{|c|}{$\begin{array}{c}\text { Comfort inside } \\
\text { classroom }\end{array}$} \\
\cline { 2 - 3 } & Yes & No \\
\hline Supported school & 4 & 4 \\
\hline Non-supported school & 3 & 6 \\
\hline Total & 7 & 10 \\
\hline $\begin{array}{l}\text { Average of Nepali and } \\
\begin{array}{l}\text { Mathematics reading (Score } \\
\text { range: } 0 \text { to 5) }\end{array}\end{array}$ & 2.29 & 1.70 \\
\hline Average in fluency & 10.99 & 11.61 \\
\hline
\end{tabular}

Table 3 shows that comfort inside classroom was found to be similar in both supported and non-supported schools. However, a slight difference was found in the non-supported schools in terms of comfort inside classroom. Out of nine schools only three schools had comfort inside classroom whereas in the supported schools it was found to be fifty-fifty. While compared with the learning achievement in terms of comfort inside classroom, there was no significantly difference in mean scores of reading comprehension and fluency. Therefore, it can be concluded that comfort inside the classroom had no effect on learning achievement of the students.

\section{Arrangement of board and its size}

Arrangement of black or white board is also equally important to teach the students. Similarly, the size of the board is also equally important from the students' point of view.

Table 4: Arrangement of board

\begin{tabular}{|l|c|c|}
\hline \multirow{2}{*}{} & \multicolumn{2}{|c|}{ Arrangement of board } \\
\cline { 2 - 3 } & Yes & No \\
\cline { 2 - 3 } Supported school & $\mathrm{N}$ & $\mathrm{N}$ \\
\hline Non-supported school & 8 & 0 \\
\hline Total & 6 & 3 \\
\hline $\begin{array}{l}\text { Average of Nepali and } \\
\begin{array}{l}\text { Mathematics reading (Score } \\
\text { range: } 0 \text { to 5) }\end{array}\end{array}$ & 2.24 & 3 \\
\hline Average in fluency & 12.00 & 0.57 \\
\hline
\end{tabular}

Table 4 depicts that all the schools of supported had black boards whereas three schools out of nine schools of non-supported schools had no black boards at all. While comparing the performance of the students, the average reading comprehension was far better in students having black board as compared to not having black boards. Fluency was also found to be far better in the schools having black board. It indicated that black/white board is very necessary to develop reading comprehension, Mathematics as well as fluency in students.

Similarly, the appropriate size of the black/white board was also observed according to the class size to ensure the impact on learning achievement of the students.

Table 5: Appropriate size of board as per class size

\begin{tabular}{|l|c|c|}
\hline \multirow{2}{*}{} & \multicolumn{2}{|c|}{$\begin{array}{c}\text { Appropriate size of boards } \\
\text { as per class size }\end{array}$} \\
\cline { 2 - 3 } & Yes & No \\
\hline Supported school & 8 & 0 \\
\hline Non-supported school & 6 & 3 \\
\hline Total & 14 & 3 \\
\hline $\begin{array}{l}\text { Average of Nepali and } \\
\text { Mathematics reading } \\
\text { (Score range: } 0 \text { to 5) }\end{array}$ & 2.24 & .57 \\
\hline Average in fluency & 12.00 & 8.36 \\
\hline
\end{tabular}

Table 5 shows that almost all the schools of supported had appropriate size of black boards whereas three schools out of nine of non-supported schools did not have appropriate size of black boards. In comparing the performance of the students, the average reading comprehension was comparatively better in students having the appropriate size of black boards than schools not having the appropriate size of black boards. Fluency was also far better in the schools having the appropriate size of black board. It is evident from the analysis that the appropriate size of black/white board is very necessary to develop reading comprehension, Mathematics as well as fluency in students.

\section{Arrangement of light in classroom}

The provision of lighting facilities plays a vital role in the psychological and biological processes of human beings. Good visual environment can only be ensured through good lighting in the classroom. It is equally important that the lighting facilities should be made natural so that it can be 
managed by minimum efforts of the school management. In the present study, the impact of lighting arrangement on learning achievement was also observed. All the observed schools had the provision of lighting facilities. The average performance of the students in reading comprehension and Mathematics skill was not satisfactory. Therefore, Lighting did not make any difference in the performance of the student in the study schools.

\section{Arrangement of ventilation in classroom}

Classroom ventilation is directly related to students' health as well as their performance. Students spend about 6 hours a day in the school or more than that. If indoor air quality is poor, it will directly affect the health of the students. They cannot perform better with their poor health. Therefore, information was collected to see the impact of ventilation in classroom in the performance of the student in reading comprehension, Mathematic skill and fluency.

Table 6: Situation of ventilation in classroom

\begin{tabular}{|l|c|c|}
\hline \multirow{2}{*}{} & \multicolumn{2}{|c|}{$\begin{array}{c}\text { Arrangement of } \\
\text { ventilation in classroom }\end{array}$} \\
\cline { 2 - 3 } & Yes & No \\
\cline { 2 - 3 } & $\mathrm{N}$ & $\mathrm{N}$ \\
\hline Supported school & 6 & 2 \\
\hline Non-supported school & 8 & 1 \\
\hline Total & 14 & 3 \\
\hline $\begin{array}{l}\text { Average of Nepali and } \\
\text { Mathematics reading (Score } \\
\text { range: O to 5) }\end{array}$ & 2.00 & 1.67 \\
\hline Average in fluency & & \\
\hline Table 6 shows & 12.45 & 6.25 \\
\hline
\end{tabular}

Table 6 shows that six out of eight supported schools and eight out of nine non-supported schools had good ventilation in their schools. Only three schools had poor ventilation in their classrooms. In comparing the achievement of the students, the average score of reading comprehension and Mathematics was slightly better in those schools where classroom ventilation was good. In contrary to the reading comprehension, fluency of the students was far better in the well-ventilated schools. Therefore, it can be concluded that well ventilation in classrooms can affect the performance of the students.

\section{Display of materials made by the students}

Display of materials made by the students in classroom is the symbol of students' achievements. It can also work as a stimulus as well as learning tool for the students. More the sense organs we use in learning more will be the learning. Display of materials will provide opportunity to visual learning. Therefore, an attempt was made to collect information on the display of materials in the classrooms.

Table 7: Display of materials in the classroom

\begin{tabular}{|l|c|c|}
\hline \multirow{2}{*}{} & \multicolumn{2}{|c|}{$\begin{array}{c}\text { Display of materials made } \\
\text { by students }\end{array}$} \\
\cline { 2 - 3 } & Yes & No \\
\cline { 2 - 3 } & $\mathrm{N}$ & $\mathrm{N}$ \\
\hline Supported school & 3 & 5 \\
\hline Non-supported school & 1 & 8 \\
\hline Total & 4 & 13 \\
\hline $\begin{array}{l}\text { Average of Nepali and } \\
\text { Mathematics reading (Score } \\
\text { range: } 0 \text { to 5) }\end{array}$ & 2.71 & 1.70 \\
\hline Average in fluency & 11.65 & 11.27 \\
\hline
\end{tabular}

It is known from table 7 that there were very few schools that displayed the materials made by students. Only four (3 supported and 1 non-supported) schools out of 17 schools used to display the materials. But the achievement levels of both the categories were the same. Scores in Nepali comprehension and Mathematics skills were slightly higher but in fluency it was almost the same. It can be concluded that display of materials had very nominal impact on students' performance in reading comprehension and Mathematics and fluency.

\section{Conclusion and Implications}

Quality and quantity of most of the physical facilities in early grades significantly affected reading in Nepali and Mathematics as well as fluency of reading in Nepali. Schools supported with physical facilities were better in relation to classroom management such as seating arrangement, arrangement of white/black board, light and ventilation arrangement, display of learning materials which correspond with better leaning among the students. Supported schools were better in terms of displaying learning materials, availability of library, availability of book corners, availability of books and regular reading opportunity in schools for students, and this positively influenced the achievements of students in reading Nepali and mathematics at early grades.

Schools need to attract children. Classroom management including pedagogy and physical facilities besides other aspects are very important to attract children to schools. Most schools in Nepal have not been able to attract children because of poor physical facilities. Unless children stop viewing schooling as burden, they do not feel like coming to schools. Effective reading at early grades depends on the availability of an overall school facilities in which teaching and learning takes place.

Developing reading habits in early grade students is the most important strategy to address the issues related to low comprehension and fluency skills in children. However, reading also depends on physical facilities. Therefore, interventions by theGovernment, I/NGOs and local level organizations in supporting the schools in improving physical facilitiesare necessary. Provision of additional reading materials to the schools; creation of adequate space for the children to play and learn; and development of children's Reading Circles through Child Clubs may be some examples in this process.

\section{Acknowledgments}

Votes of thanks go to the teachers who promptly provided information and allowed to observe their classes. All the college administrators are thankful for providing the study area.

\section{REFERENCES}

[1] Council NR. Preventing reading difficulties in young children National Academies Press; 1998.

[2] Gove A, Cvelich P. Early reading: Igniting education for all. A report by the early grade learning community of practice. RTI International. 2011 .

[3] Gulemetova M, Dessein L, Safarha ME, Manzoni L, Aldrette JH, Bahati E. Integrated Support for Sustainable School Canteens and Early Grade Reading in Ivory Coast (2016-2020). 2016.

[4] Mantrālaya NŚ. School Sector Reform Plan, 2009-2015: Ministry of Education, Government of Nepal; 2009. 
[5] Akhihiero ET, editor Effect of inadequate infrastructural facilities on academic performance of students Of Oredo Local Government Area of Edo State. The Nigerian Academic Forum; 2011.

[6] Mokaya ZM. Influence of School Infrastructure on Students' Performance in Public Secondary Schools in Kajiado County, Kenya. A Research Proposal Submitted in Partial Fulfillment of the Requirements for the Award of the Degree of Master of Education in Corporate Governance, University of Nairobi. 2013.

[7] Akomolafe CO, Adesua VO. The Impact of Physical Facilities on Students' Level of Motivation and Academic Performance in Senior Secondary Schools in South West Nigeria. Journal of Education and Practice. 2016;7(4):38-42.

[8] McGowen RS. The impact of school facilities on student achievement, attendance, behavior, completion rate and teacher turnover rate in selected Texas high schools: Texas A\&M University; 2007.

[9] Adesua C. The Impact of Physical Facilities on Students' Level of Motivation and Academic Performance in Senior Secondary Schools in South West Nigeria. Journal of Education and Practice. 2016.

[10] Schneider M. Do School Facilities Affect Academic Outcomes? 2002.

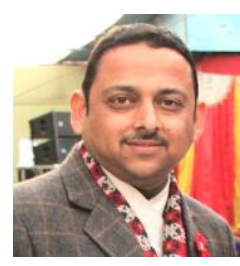

BhagwanAryal, $\mathrm{PhD}$,is assistant Professor in Central Department of Education, Tribhuvan University, Nepal. Besides teaching and supervising theses and dissertations of Master and M.Phil. level students, he is involved in research and evaluation of a number of social and educational projects including early grade reading, child marriage, sexual and reproductive health, health education and promotion. 